\title{
Reproductive Biology of Actinopyga echinites and Other Sea Cucumbers from La Réunion (Western Indian Ocean): Implications for Fishery Management
}

\author{
Sophie Kohler $^{*}$, Sylvie Marylène Gaudron² and Chantal Conand ${ }^{1}$ \\ ${ }^{1}$ ECOMAR, Université de La Réunion, Av. René Cassin, 97715 Saint-Denis, France; ${ }^{2}$ UPMC Université Paris \\ 06, UMR 7138 F-75005 Paris, France
}

Keywords: Sea cucumber, Actinopyga echinites, Aspidochirotid holothurians, reproductive season, first sexual maturity, fishery management, La Réunion, Western Indian Ocean

\begin{abstract}
The sea cucumber fishery is important in several countries of the Western Indian Ocean (WIO) but is generally not adequately managed. A regional MASMA programme (Marine Science for Management) granted by WIOMSA (Western Indian Ocean Marine Sciences Association) is providing data on the reproduction of some commercial species. In La Réunion, the two target species are Actinopyga echinites and Holothuria leucospilota. These sea cucumbers are very abundant on the fringing reefs and were sampled monthly during 2005-2006. Data on the population structure and on the reproductive cycle of A.echinites are presented here. The main results are: 1) eviscerated weight $(\mathrm{EW})$ distribution of individuals within the population of Planch'Alizés site is plurimodal with a main mode at $85-95 \mathrm{~g}, 2$ ) sex-ratio is skewed toward females, 3) anatomy of gonads is described in five maturity stages, 4) a seasonal reproductive cycle with a major spawning event in December-January and a minor spawning event in April, 5) size at first sexual maturity $\mathrm{EW}_{50}$ equal to $45 \mathrm{~g}$ is determined from another site (a sea grass bed with juveniles). These results are integrated with data from other holothurian species such as H. leucospilota, H. atra and Stichopus chloronotus previously studied in La Réunion and will be useful for research on the reproductive biology of sea cucumbers conducted in the other countries of WIO. 'Seasonal closure' using results on the spawning season during the warm waters period and 'minimum size' using size at first sexual maturity are tools for enhancing sustainable management of the fisheries.
\end{abstract}

\section{INTRODUCTION}

Sea cucumbers are prized by oriental populations for their dried body wall known as bêche-de-mer ('trepang' or 'hai-som') and constitute therefore an important resource of commercial value in coastal fisheries (Conand 1989, 2001, 2004a, 2008). Worldwide demand of this marine product has increased the fishing pressure and has lead to over-exploitation (Conand, 2004a, 2006a, 2006b) Countries of the Western Indian Ocean (WIO) have traded sea cucumbers for hundred of years, however only recently they have been interested in their management (Conand, 1989, 2008; Conand et al., 2006; Conand and Muthiga, 2007) which needs investigations on their biology including reproduction. A regional multidisciplinary MASMA programme (Marine Science for Management) granted by WIOMSA (Western Indian Ocean Marine Science Association) is underway in the WIO that will bring data on the reproduction of the most important bêche-de-mer species (Conand et al., 2006; Conand and Muthiga, 2007). In La Réunion, the two target species are Holothuria 
leucospilota and Actinopyga echinites which are very abundant on the fringing reefs. Reproductive biology has been studied for H. leucospilota (Gaudron et al., 2008) but information for $A$. echinites is still needed. This latter species was studied in the tropical Pacific by Shelley (1981) and Conand $(1982,1989)$ and in Taiwan by Chao et al. (1995).

A. echinites (common name 'deep-water redfish') is a medium-sized species whose tegument varies in colour, from light brown to orange. It has numerous papillae dorsally and its anus is ringed by five calcareous teeth. It is a common species fished on the shallow reef flats of the WIO (Conand and Muthiga, 2007). On La Réunion reefs, A. echinites is mostly found on outer reef flats with oxygenated waters and lives exposed on the hard substrate, with a maximum density of $3 \mathrm{ind} / \mathrm{m}^{2}$ (Conand and Mangion 2002; Conand 2008).

\section{Fishery management of holothurians in the WIO}

The management of sea cucumber fisheries to enhance sustainability is becoming an important issue in many regions (Lovatelli et al., 2004; Bruckner, 2006; Conand, 2006a, 2006b, 2008). It requires data on the population dynamics of the commercial species, which are generally still lacking. The sexual reproduction, if seasonal, is important to implement a harvest season and closure during the spawning. The size at first maturity (Conand, 2006a, 2008) is necessary to limit capture sizes which has a biological justification in maximizing the yield per recruit and allow individuals to spawn before harvest, and also an economic reason as larger individuals command a better price than smaller ones. The present results for A. echinites and the already published results for other species from La Réunion are presented as a synthesis useful for future management in the WIO.

This study investigates biological aspects of the reproduction of $A$. echinites including size distribution of individuals, sex-ratio, anatomy of gonads, seasonal reproductive cycle and size (eviscerated weight) at first sexual maturity. Results from the present study, the first on the reproduction of A. echinites in the Indian Ocean, are compared with data from other sites where this species has been studied and from other holothurian such as H. atra, Stichopus chloronotus and H. leucospilota, previously studied in La Réunion (Conand et al., 1997, Conand et al., 1998, Hoareau and Conand 2001, Uthicke et al., 2001; Conand et al., 2002; Uthicke and Conand 2005, Gaudron et al., 2008). Results will be useful for the research on the reproductive biology of sea cucumbers conducted in the other countries of the WIO, as for H. scabra (Muthiga et al., 2007, Rasolofonirina et al., 2005). Management of the stocks is now an urgent issue at national and regional levels (Lovatelli et al., 2004, Conand 2008). The spawning season and the size at first sexual maturity will be useful for a future regional management of the stocks.

\section{MATERIAL AND METHODS}

Actinopyga echinites specimens were collected by snorkelling over the reef of La Saline in La Réunion $\left(21^{\circ} 07^{\prime} \mathrm{S}, 55^{\circ} 32^{\prime} \mathrm{E}\right)$. The species is abundant on the outer reef flat at the Planch'Alizés site. From September 2005 to October 2006, 18 sea cucumbers were collected bimonthly and placed into a solution of $\mathrm{MgCl}_{2}(5 \%)$ in seawater prior to dissection. As smaller individuals were observed in a nearby seagrass bed, in December 2006, one additional sample was collected at this site. Biometric measurements recorded before specimens were dissected were: total length (TL) from mouth to anus to the nearest $0.5 \mathrm{~cm}$ and total weight (TW) to the nearest $1 \mathrm{~g}$. The whole gonad, including the gonad basis and germinal tubules located at the anterior-dorsal part of the body, was removed, weighed (Gonad Weight - GW) to the nearest $0.1 \mathrm{~g}$ and fixed in $7 \%$ buffered formaldehyde. The eviscerated weight (EW) or gutted body with all its organs removed, was weighed to the nearest $1 \mathrm{~g}$. The gonad index (GI) was calculated using the equation, $G I=\frac{G W}{E W} \times 100$ (Conand, 1981, 1982, 1989, 1993; Gaudron et al., 2008) where GI is gonad index (\%), GW is gonad weight and EW is eviscerated body weight. The latter parameter has been chosen over total weight because it is less variable (Conand, 1981). For each preserved gonad, maturity was assessed using a five-stage maturity scale as used for other species (Conand, 1981, 1982, 1993; Gaudron et al., 2008), based on 
macroscopic and microscopic features. Gonads were fixed in Bouin fixative for one week and stored in $70 \%$ ethanol before being dehydrated in graded ethanol, embedded in paraffin, cut into $5 \mu \mathrm{m}$ slices mounted and stained in Haematoxylin-Eosin. Serial sections were observed under light microscopy. In the resting (stage 1) and immature (stage 2) stages, sex could not be established visually compared to growing stage (stage 3 developing gonads), maturation stage (stage 4 maturing gonads) and post-spawning stage (stage 5 spent gonads). The other observations include tubule length and diameter, gonad colour and form and, mode of oocyte diameter measured from a smear of the longest tubule. A scale of 'atresia' (phenomenon due to disintegration of germinal cells within the fecund tubules) was proposed for $S$. chloronotus based on its importance (Conand et al., 2002) and was used here, where 'atretic' gametes generally occurred as brown patches.

Weight at first sexual maturity was not determined for specimens from the Planch'Alizés site, as all the individuals were either maturing or mature during the reproductive period. Instead, 40 smaller specimens of A. echinites were sampled from a nearby site of seagrass bed of the same reef in December 2006. First sexual maturity was defined as the eviscerated weight at which gonads of $50 \%$ of specimen were undergoing gametogenesis $\left(\mathrm{EW}_{50}\right)$ during the breeding season (see Conand, 1981, 1993). It was calculated by plotting the percentage of specimen with developing gonads of stage 3,4 and 5 against classes of EW.

Data of sea temperature (in ${ }^{\circ} \mathrm{C}$ ) were from Conand et al. (2007), which was a study of 10 years of the sea surface temperature in Le Port $\left(20^{\circ} 55^{\prime} \mathrm{S}\right.$, $55^{\circ} 17^{\prime} \mathrm{E}$ ) and, solar radiation (joules.month ${ }^{-1}$. $\left.\mathrm{cm}^{-2}\right)$ and rainfall $(\mathrm{mm})$ were from Trois-Bassins $\left(21^{\circ} 05^{\prime} \mathrm{S}, 55^{\circ} 15^{\prime} \mathrm{E}\right)$, fifteen kilometres south of the studied reef La Saline during 2005-2006 (Météo France, www.meteo.fr).

The relationships between the timing of reproduction of A. echinites using the GI and the environmental factors (sea temperature, illumination, rainfall) were correlated, as presented for H. leucospilota (Gaudron et al., 2008).

Statistical analyses were performed using Student's test ( $t$-test) to compare differences between males and females for EW, GW, length and diameters of tubules, in order to highlight possible sexual dimorphism. A sex ratio was calculated and significance was measured by using a Chi-squared test. To determine whether gonad index differed between months, monthly mean GI were compared by using an unbalanced one-way ANOVA and significant difference was assessed by using a posthoc Tukey test (SPSS11.0 software). Normality of data was assessed by using K-S test (KolmogorovSmirnov test).

\section{RESULTS}

\section{Reproductive biology of Actinopyga echinites}

\section{Biometric measurements}

A total of 160 A. echinites were sampled from the reef of La Saline at Planch'Alizés in La Réunion during the 13-month collection in 2005-2006. Total weight (TW) of specimens collected at Planch'Alizés site ranged from $69 \mathrm{~g}$ to $650 \mathrm{~g}$. Eviscerated body weight (EW) of these sea cucumbers ranged from $49 \mathrm{~g}$ to $248 \mathrm{~g}$ (Figure 1A) where females were significantly heavier than males ( $t$-test; Table 1$)$.

The sample from the seagrass bed (Figure 1B) is composed of smaller individuals with a modal eviscerated weight of $40 \mathrm{~g}$; the dissection showed that these were juveniles, which are rarely found in the field.

The TW was correlated significantly with the $\mathrm{EW}(r=0.88, P<0.001, n=155$; Figure 2). A. echinites of Planch'Alizés has a mode of EW ranging from $85-95 \mathrm{~g}$ (Figure 1A). By using the regression line in Figure 2, this mode of EW equals a mode for total weight of $150 \mathrm{~g}$. During the breeding season, gonads of both sexes were weighed and sexual dimorphism was significantly revealed only by tubule diameters where female features were greater than male features ( $t$-test; Table 2).

\section{Sex ratio}

From the 160 A.echinites sampled at Planch'Alizés, 94 were female, 47 male and 18 specimen of undetermined sex, giving a sex ratio significantly different from $1: 1\left(\chi^{2}=15.7 ; P<0.001\right)$ and closer to a 1:2 ratio. Undetermined sex specimens (resting stage and immature stage) were encountered from June to October (Figure 3). 


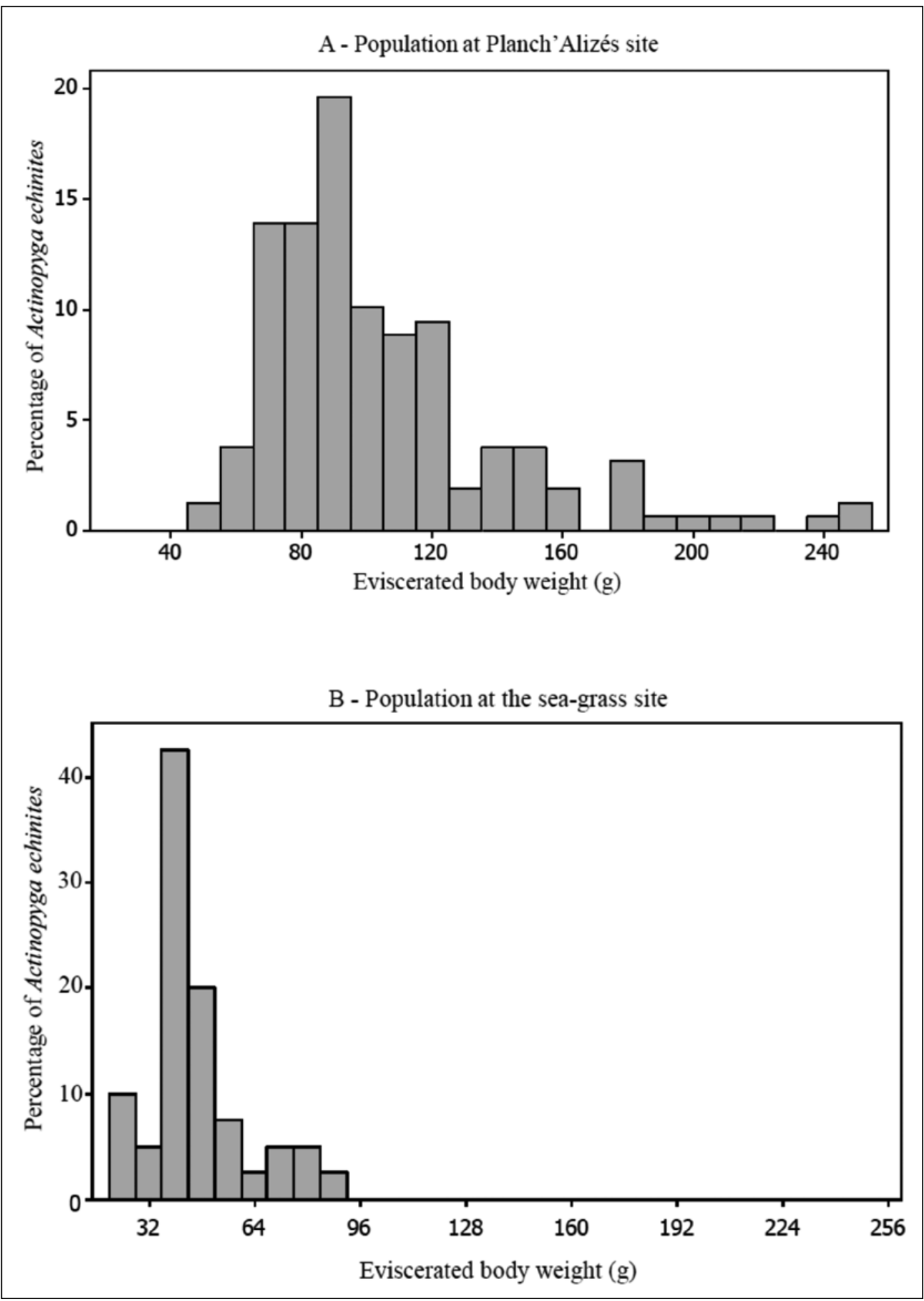

Fig. 1. Eviscerated body weight frequencies distributions in the population of Actinopyga echinites in La Réunion, from: A- Planch'Alizés site $(n=160)$; B- seagrass site $(n=40)$ 
Table 1: Biometric characteristics of male and female Actinopyga echinites from September 2005 to September 2006. Data are mean and standard error of the mean (SEM). Differences between biometrics data of male and female were tested by Student's $t$-test at $95 \%$ of confidence

\begin{tabular}{lllll}
\hline Biometric data & Male & Female & Overall & $P$ \\
\hline Eviscerated weight $(\mathrm{EW})(\mathrm{g})$ & $96.3 \pm 5.4$ & $112.3 \pm 4.1$ & $107.0 \pm 3.3$ & $*$ \\
Gonad weight $(\mathrm{GW})(\mathrm{g})$ & $11.1 \pm 1.6$ & $13.6 \pm 1.3$ & $12.8 \pm 1.0$ & 0.247 \\
Gonad index $(\mathrm{GI})(\%)$ & $11.9 \pm 1.5$ & $11.9 \pm 1.0$ & $11.9 \pm 0.9$ & 0.991 \\
Tubule length (mm) & $54.7 \pm 3.4$ & $51.0 \pm 2.0$ & $51.6 \pm 1.8$ & 0.225 \\
Tubule diameter (mm) & $1.1 \pm 0.04$ & $1.3 \pm 0.04$ & $1.2 \pm 0.03$ & $* * *$ \\
\hline
\end{tabular}

* Statistical significance

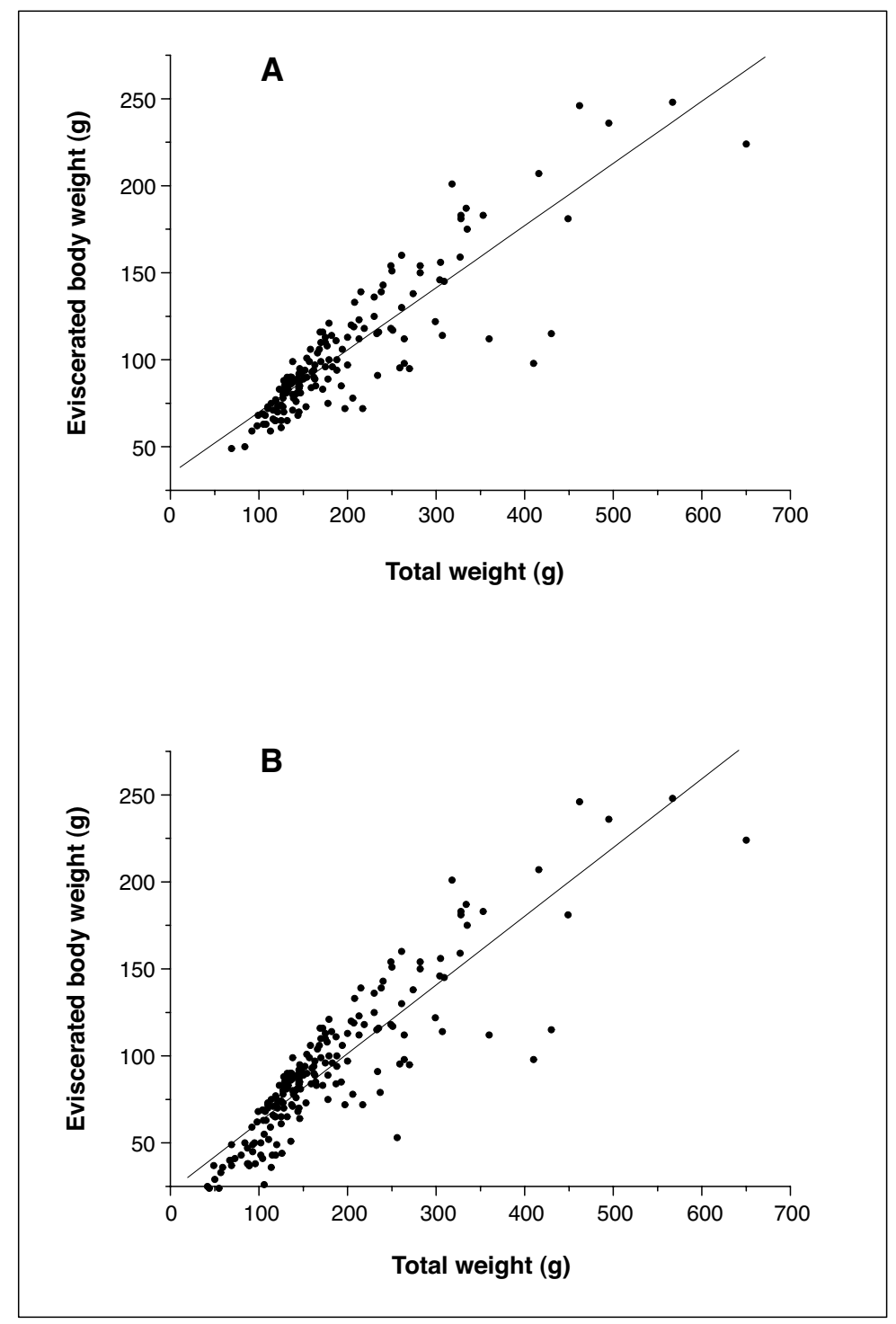

Fig. 2. Relationship between total weight (TW) and eviscerated body weight (EW) in g of Actinopyga echinites specimens collected from: A- Planch'Alizés $(n=155)$ in La Réunion from September 2005 to October $2006(\mathbf{r}=0.88, \mathbf{P}<0.001)$ $(y=34.26+0.36 x)$; B- $(n=195)$ Planch'Alizés and seagrass bed in La Réunion from September 2005 to December 2006 $(\mathrm{r}=0.88, \mathrm{P}<0.001)(\mathrm{y}=22.41+0.39 \mathrm{x})$ 
Table 2: Correlation of the mean monthly gonad index (GI) and environmental parameters

\begin{tabular}{llcc}
\hline Comparison of mean gonad index with & Correlation & r (Pearson) & $\boldsymbol{P}$ \\
\hline Mean monthly sea temperature & $y=0.4 x-1.8$ & 0.11 & 0.82 \\
Mean monthly illumination & $y=2.2 x-32.3$ & 0.75 & 0.09 \\
Cumulated montly rainfall & $y=0.02 x+7.6$ & 0.23 & 0.62 \\
\hline
\end{tabular}

* Statistical significance

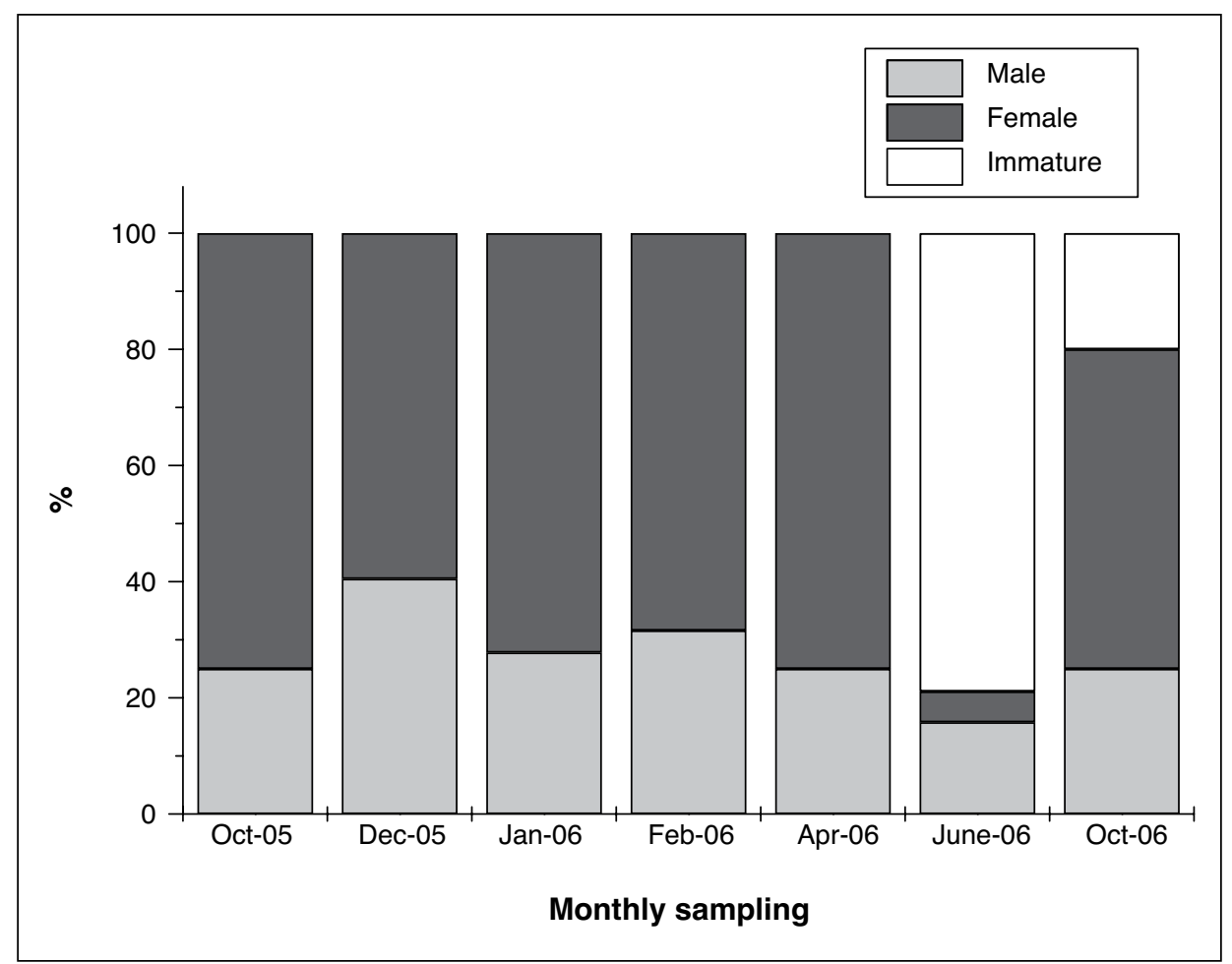

Fig. 3. Actinopyga echinites sex-ratio. Percentage of males, females and immature individuals at Planch'Alizés (October 2005 to October 2006)

\section{Gametogenesis}

Macroscopic and histological observations of gonads allowed the description of five gametogenic stages. Immature (stage 1) and resting (stage 2) stages were very similar and the size at first sexual maturity of specimen will allow distinguishing between these two stages. Gonads in growing stage (stage 3 ) exhibited much variability in colour, gonadal tubules length and in the size distribution of oocytes within tubules. Specimen in maturing stage (stage 4) had the largest tubules and were full either of ripe oocytes, between 150-160 $\mu$ m modal diameters (figure 4 ) or mature sperm.
Post-spawning gonads (stage 5) were again highly variable and 'Atresia' was generally limited.

The percentage of specimens in each different stage is shown for each bimonthly sample in Figure 5. Both in October 2005 and 2006, there was the same predominance of the growing stage (stage 3 ). Then the maturing stage (stage 4) became dominant in December and January. In February, the post spawning stage (stage 5) was observed in about $80 \%$ of individuals and decreased in April (60\%) where the maturing stage again became more dominant.

Mean monthly gonad-indices of $A$. echinites (Figure 6) displayed a seasonal pattern of 


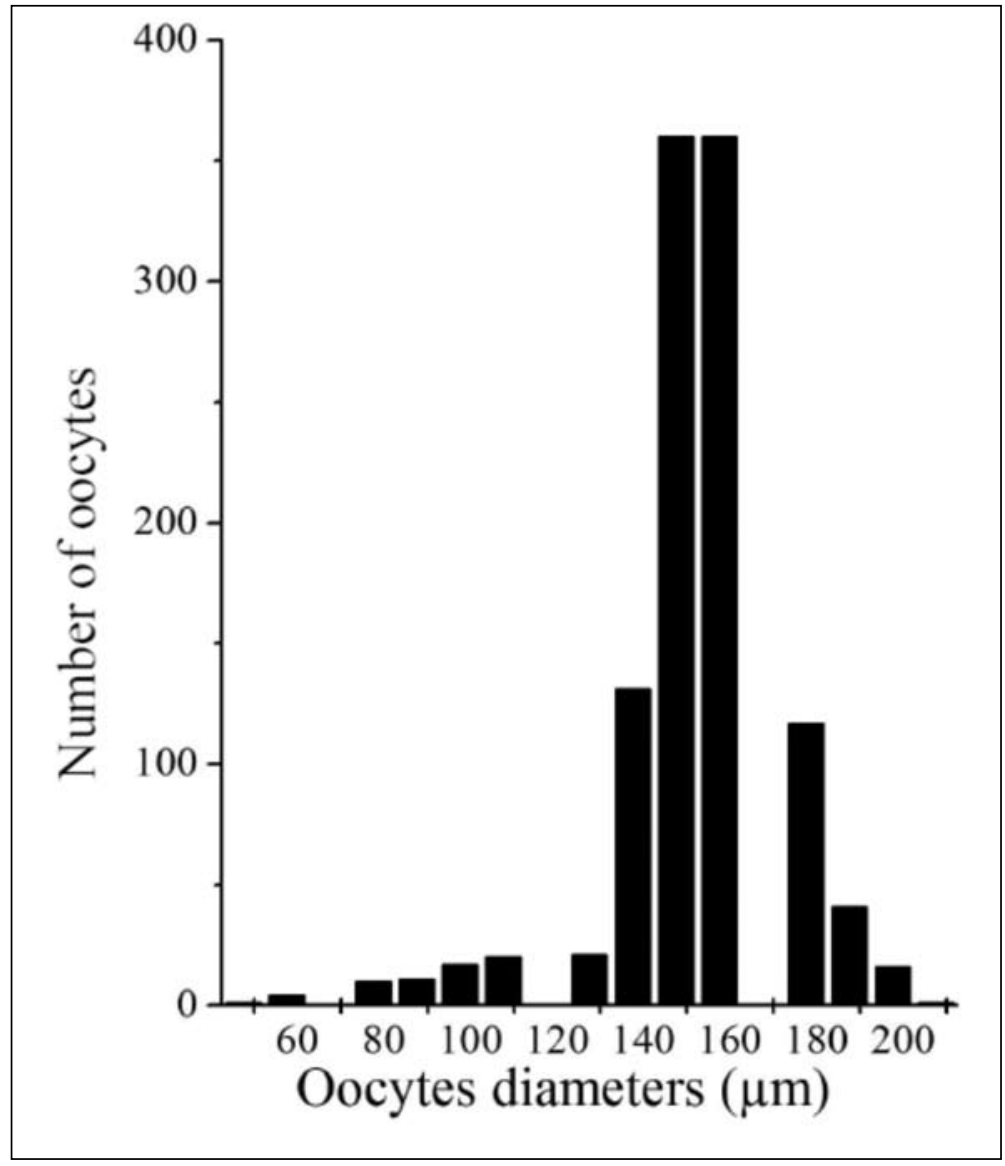

Fig. 4. Frequency of oocytes diameters of females Actinopyga echinites in stage 4 (maturing stage) from December to April showing a main mode of oocytes diameters of 150-160 $\mu \mathrm{m}$

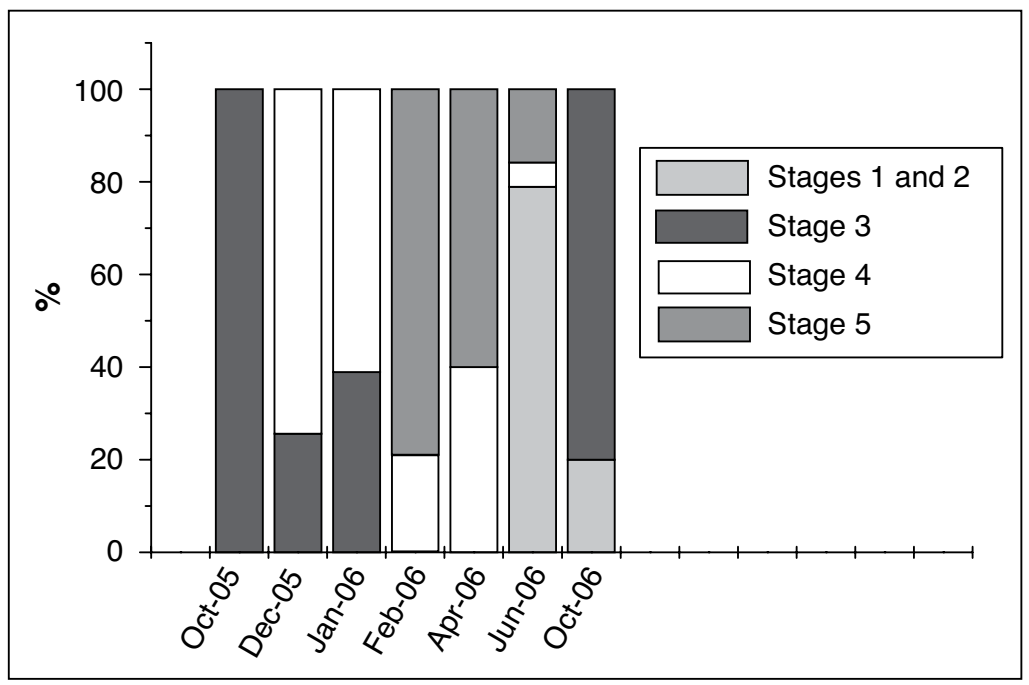

Figure 5. Actinopyga echinites gametogenic condition of specimens collected from September 2005 to October 2006. Histograms are showing percentages of individuals in one of the five gametogenic stages: resting, immature, growing, maturing and post-spawning 
reproduction showing a major spawning event, deduced by a strong increase of GI from October $(\mathrm{GI}=4.55 \pm 0.6 \%)$ to a maximum in December (GI=21.0 $\pm 1.4 \%)$ followed by a decline until February $(\mathrm{GI}=6.3 \pm 0.9 \%)$ indicating that gametes were released during this two-month period (see also Figure 5). GI was slightly peaking again in April $(9.5 \pm 1.7 \%)$, followed by a second decrease until June $(\mathrm{GI}=1.5 \pm 1.1 \%)$ revealing a minor second spawning event within this month. Monthly comparison of mean GI of $A$. echinites during the annual cycle, using an unbalanced one-way ANOVA, was found to be significantly different $\left(\mathrm{F}_{(1,6)}=27.92 ; P<0.001\right)$. A post-hoc test $(t$-test $)$ confirmed that the significant difference was mainly due to mean GIs calculated in December 2005 and January 2006 (Fig. 6).

\section{Reproductive cycle: environmental factors and gonad index}

The mean monthly sea temperature in Le Port recorded for ten years (Figure 7A) exhibited a seasonal pattern peaking in February and March where mean monthly temperature reached a maximal of $27.9^{\circ} \mathrm{C}$, with the minimal monthly mean temperature found in September $\left(23.4^{\circ} \mathrm{C}\right)$. There was no correlation between sea temperature and GI (see Table 2; $\mathrm{r}=0.11$ and $\mathrm{P}=0.82$ ). Mean monthly GIs increased with increasing temperature from October to December during gamete development, but thereafter no correlation remained (Figure 7A). However, there was a stronger correlation between light illumination and gonad index (Table 2; r=0.75 and $\mathrm{P}=0.09$ ), where GI increased from June to December while illumination was increasing, and GI decreased from January to May when illumination was falling (Fig. 7B). There was no correlation between rainfall and GI (Fig. 7C; Table 2).

\section{Weight at first sexual maturity}

The weight at first sexual maturity (Figure 8 ) in which $50 \%$ of A.echinites were in stages 3,4 and 5 was found to have a mode of 46-55g of EW, equal to a total weight of $65 \mathrm{~g}$.

\section{DISCUSSION}

\section{Synthesis on sexual reproduction of La Réunion Holothurians}

Previous studies have been conducted in $\mathrm{La}$ Réunion on several species: Holothuria atra

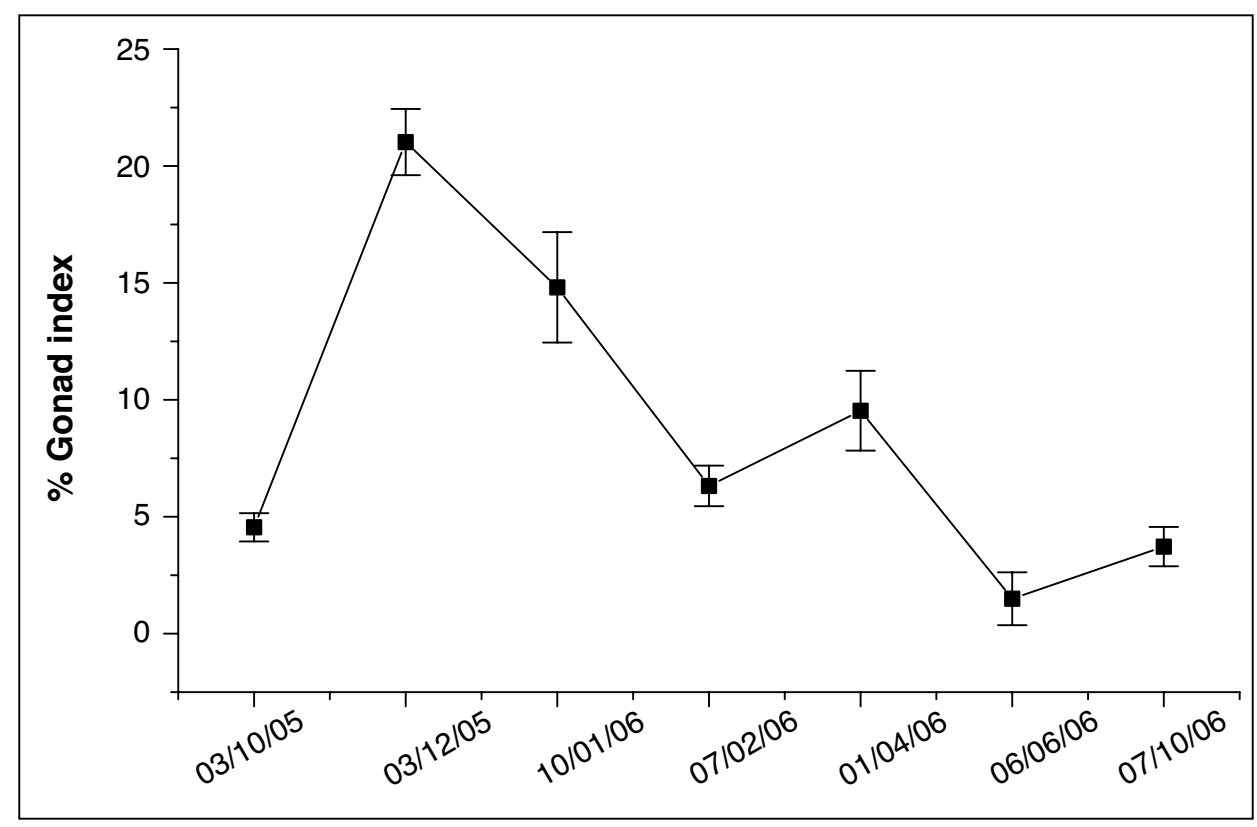

Fig. 6. Monthly variation of mean gonad-indices of Actinopyga echinites. Data are mean values for the specimens collected and Standard Error of the Mean (SEM) 


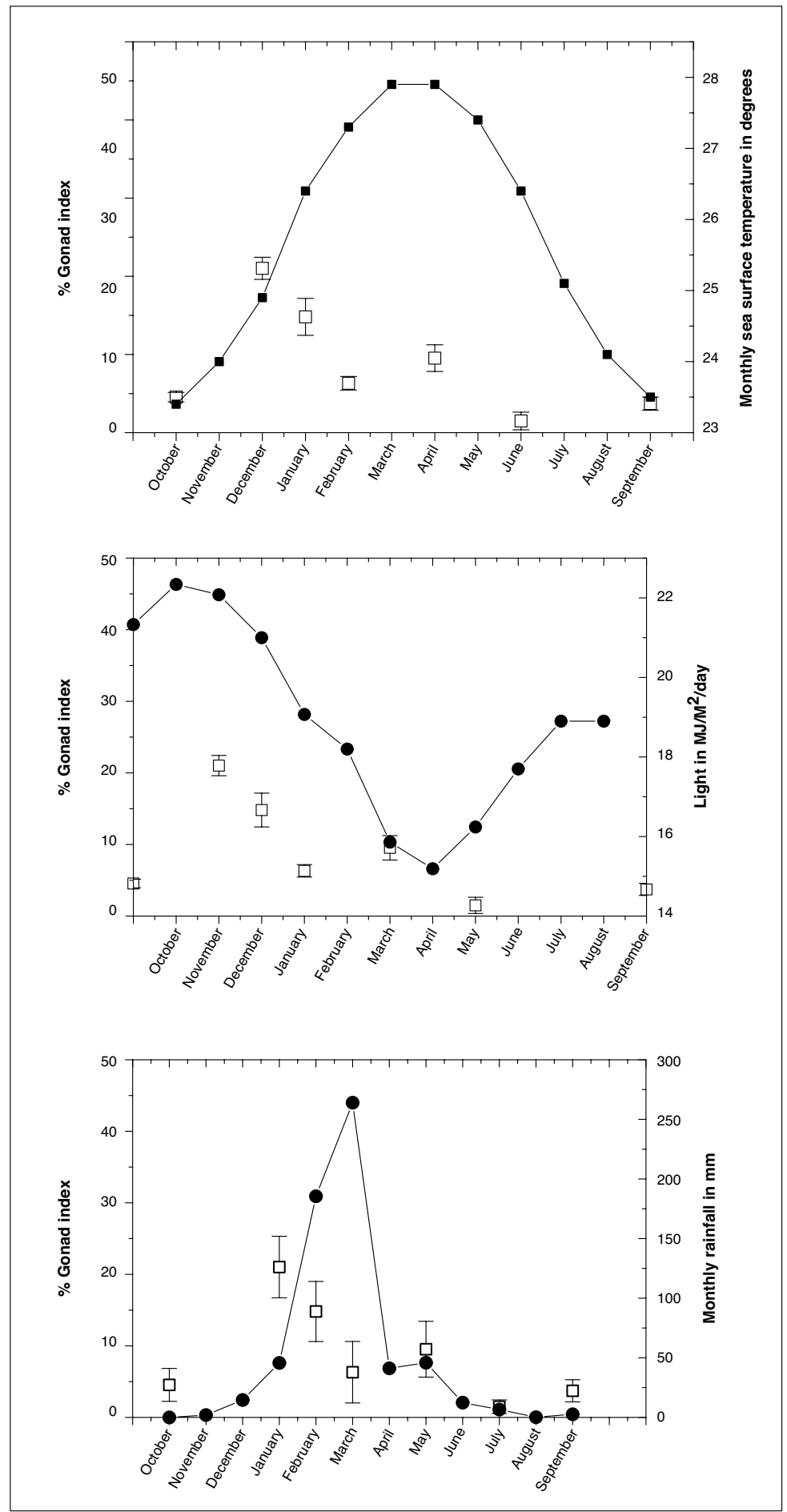

Fig. 7. Actinopyga echinites mean monthly gonad index (open square) against environmental parameters (dark circle) A-Mean sea surface temperature data (from Conand et al., 2007) recorded hourly in Le Port (La Réunion) during 10 years from 1993 to 2004. B- Mean daily illumination, expressed as days in mega joules per meter square, recorded by the French Meteorological station (www.meteofrance.com) at Trois Bassins $\left(21^{\circ} 05{ }^{\prime} 30^{\prime \prime} \mathrm{S} ; 5^{\circ}{ }^{\prime} 15^{\prime} 12^{\prime} ' \mathrm{E}\right)$ between the 01/09/2005 to 30/09/2006. C- Cumulated monthly rainfall in mm, recorded by the French Meteorological station (www.

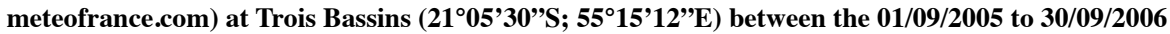




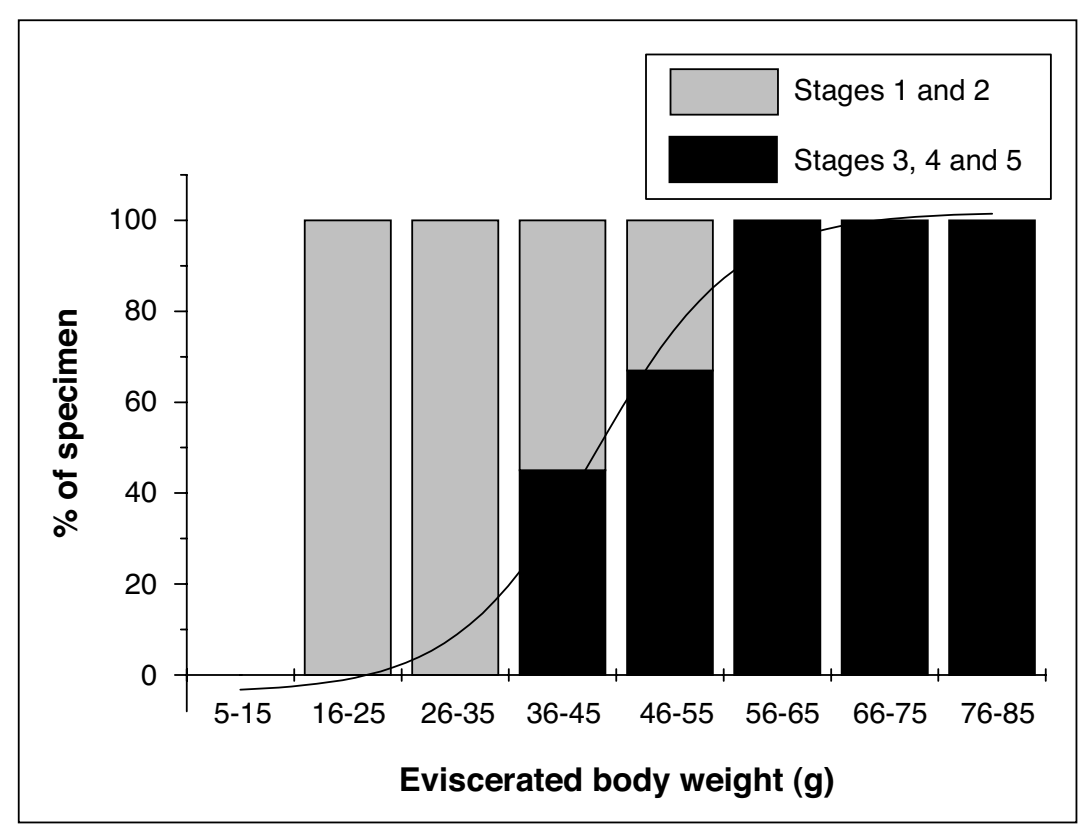

Fig. 8. Weight at first sexual maturity Actinopyga echinites: stage 1 (resting), stage 2 (immature), stage 3 (growing), stage 4 (maturation) and stage 5 (post-spawning) from the sampling in the sea-grass site in December 2006

(Conand, 1996; Conand, 2004b), H. leucospilota (Conand et al., 1997; Gaudron et al., 2008) and S. chloronotus (Hoareau and Conand, 2001; Conand $e t$ al., 1998, 2002; Uthicke and Conand, 2005). Table 3 synthesises the main results obtained for these three holothurians plus A. echinites, on population parameters (3A) and reproductive biology (3B) from several sites of La Réunion reefs.
Mean densities were very variable for both $H$. atra and $S$. chloronotus, showing values higher than $1 / \mathrm{m}^{2}$ in some sites, and lower on other sites. A. echinites population is generally not dense, but was present on large areas on reef flats of the reef sites (Saint Gilles, Saint Leu, Etang Salé and Saint Pierre), with densities generally between 0.01 and $0.2 / \mathrm{m}^{2}$ (Conand and Mangion, 2002). The modal

Table 3: Synthesis of the holothurian population parameters studied from La Réunion; A: population; B: reproduction

\begin{tabular}{|c|c|c|c|c|c|c|}
\hline \multirow{2}{*}{$\begin{array}{l}\text { A Species } \\
\text { Holothuria atra }\end{array}$} & \multicolumn{2}{|l|}{ Site } & \multicolumn{2}{|c|}{ Density } & \multicolumn{2}{|c|}{ Weight modal value (g) } \\
\hline & \multirow{2}{*}{\multicolumn{2}{|c|}{$\begin{array}{l}\text { Planch'Alizés BR } \\
\text { Planch'Alizés RF }\end{array}$}} & \multicolumn{2}{|c|}{$4.0 / \mathrm{m}^{2}$} & \multicolumn{2}{|l|}{50} \\
\hline & & & \multicolumn{2}{|c|}{$\inf 0.01 / \mathrm{m}^{2}$} & \multicolumn{2}{|l|}{160} \\
\hline \multirow[t]{2}{*}{ Stichopus chloronotus } & \multicolumn{2}{|c|}{ Trou d'Eau } & \multicolumn{2}{|c|}{$3.6 / \mathrm{m}^{2}$} & \multicolumn{2}{|l|}{40} \\
\hline & \multicolumn{2}{|l|}{ Etang Salé } & \multicolumn{2}{|c|}{$1.5 / \mathrm{m}^{2}$} & \multicolumn{2}{|l|}{60} \\
\hline Holothuria leucospilota & \multicolumn{2}{|c|}{ Planch'Alizés BR } & \multirow{2}{*}{\multicolumn{2}{|c|}{$\begin{array}{l}0.8 / \mathrm{m}^{2} \\
\inf 0.1 / \mathrm{m}^{2}\end{array}$}} & \multirow{2}{*}{\multicolumn{2}{|c|}{$\begin{array}{l}300 \\
107\end{array}$}} \\
\hline Actinopyga echinites & \multicolumn{2}{|c|}{ Planch'Alizés IRF } & & & & \\
\hline B Species & Sites & $\begin{array}{l}\text { Sex-ratio } \\
\text { (M:F) }\end{array}$ & $\begin{array}{c}\text { Main } \\
\text { season }\end{array}$ & $\begin{array}{l}\text { Secondary } \\
\text { season }\end{array}$ & $\begin{array}{l}\text { Mean GI } \\
(\%)\end{array}$ & $\begin{array}{c}\text { First } \\
\text { maturity } \\
\text { (EW g) }\end{array}$ \\
\hline Holothuria atra & Planch'Alizés & - & Warm Season & None & - & - \\
\hline Stichopus chloronotus & Trou d'Eau & $31: 1$ & Jan-Feb & Nov & 4.6 & 50 \\
\hline Holothuria leucospilota & Planch’Alizés (BR) & $1: 9$ & Feb & May & 42.0 & 55 \\
\hline Actinopyga echinites & Planch’Alizés (IR) & $1: 2$ & Dec - Jan & April - May & 11.9 & $46-55$ \\
\hline
\end{tabular}


TW and EW values, as in many populations studied in La Réunion (Conand 1989, Gaudron et al. 2008) appeared unimodal. The weight at first sexual maturity for A. echinites $\mathrm{EW}_{50}$ was $46-55 \mathrm{~g}$, which corresponds to $65 \mathrm{~g}$ of TW. This value is of the same range of the $\mathrm{EW}_{50}$ found for $S$. chloronotus $(50 \mathrm{~g})$ and $H$. leucospilota $(55 \mathrm{~g})$.

\section{Reproductive parameters and cycle of Actinopyga echinites in different sites}

Despite a high level of exploitation in the IndoPacific countries (Conand 2006a, 2008) the ecology and reproduction parameters of Actinopyga echinites (commercial name deep-water redfish) has been studied in only three locations from the tropical Pacific, where it is a common species (Clark and Rowe 1971): 1) Papua New Guinea (PNG) (Shelley, 1981), 2) New Caledonia (Conand, 1982, 1989, 1993), and 3) Taiwan (Chao et al., 1995). The present study is the first on the reproduction of $A$. echinites in the Indian Ocean. The present knowledge on distribution and abundance of $A$. echinites is that populations live on reef flats, mostly in wind-exposed sites in the four locations cited previously. Juveniles have been found on seagrass beds in Okinawa in August, which had allowed the study of their growth during one year (Wiedemeyer, 1994), and, in PNG (Shelley 1981) and in La Réunion (this study), on a seagrass bed of the back reef. The density in New Caledonia (Conand 1982) was about $0.08 / \mathrm{m}^{2}$, in PNG it was $0.18 / \mathrm{m}^{2}$ (Shelley 1981) and in La Réunion at Planch'Alizés it was $2 /$ $\mathrm{m}^{2}$ (Conand and Mangion 2002), much less than in the seagrass bed were the juveniles were found in December 2006 (this study) in a dense patch of 5/ $\mathrm{m}^{2}$. As for other sea cucumbers, the density varied considerably between sites. The main results from these studies are summarized in Table 4.

The length (or weight) frequency distribution in the populations studied was very variable and specimens of A.echinites were generally mediumsized.

The sex ratio in A. echinites has been found not significantly different from $1: 1$, except in La Réunion where an unbalanced sex-ratio was observed, and also in species undergoing fission like S. chloronotus (31:1) and H. leucospilota (1:9) (Conand et al., 2002; Gaudron et al., 2008). It is the first observation of unbalanced sex-ratio for a non-fissiparous species. Further sampling should be undertaken to demonstrate if this is due to segregation in spatial distribution of sexes within a population, or resulting from other mechanism.

The gonad anatomy and the characteristics of the 5 maturity stages do not show differences between the four populations presented in Table 4 .

Gonad-indices and biometric relationships between parameters such as TL, TW, DW (Drained Weight) and EW need to be standardised for comparisons between different populations of $A$. echinites. GI was very useful to determine the spawning season, as observations of spawning in the field are very scarse. For instance, spawning of A. echinites has been recorded only twice: in December the $10^{\text {th }} 1980$ in PNG (Shelley, 1981) and in February 1979 in New Caledonia (Conand, 1982). More attention should be paid in the future to this common commercial species. The spawning season of A. echinites in Taiwan (Northern hemisphere) was between May-July (with a first small decrease in March) and mean maximal gonad-

Table 4: Synthesis of $A$. echinites reproductive characteristics from studies from several sites from the IndoPacific

\begin{tabular}{|c|c|c|c|c|c|c|c|}
\hline $\begin{array}{c}\text { Sites and } \\
\text { latitude } \\
\text { (EWg) }\end{array}$ & $\begin{array}{c}\text { Weight } \\
\text { modal value }\end{array}$ & $\begin{array}{c}\text { Sex-ratio } \\
\text { (M:F) } \\
\text { (GW/EW) }\end{array}$ & $\begin{array}{l}\text { Max Gonad } \\
\text { Index }\end{array}$ & $\begin{array}{c}\text { Main } \\
\text { spawning } \\
(\mu \mathrm{m})\end{array}$ & $\begin{array}{c}\text { Oocyte } \\
\text { diameters } \\
\left(\mathbf{E W}_{50}\right)\end{array}$ & $\begin{array}{c}\text { First } \\
\text { maturity }\end{array}$ & Reference \\
\hline \multicolumn{8}{|l|}{ Papua New } \\
\hline Guinea $-10^{\circ} \mathrm{S}$ & - & 0.95: 1 & 18 to 22 & Dec-Feb & 150 & - & Shelley 1981 \\
\hline New Caledonia- & & & & & & & \\
\hline $21^{\circ} \mathrm{S}$ & 188 & $1: 0.9$ & 13 & Jan-Feb & 160 & 67 & Conand 1982,1993 \\
\hline Taiwan- $23^{\circ} \mathrm{N}$ & - & $1: 1$ & 23 & Jun-Jul & 110 & - & Chao et al. 1995 \\
\hline $\begin{array}{l}\text { La Réunion- } \\
21^{\circ} \mathrm{S}\end{array}$ & $90($ mean 107$)$ & $1: 2$ & 22 (mean 11.9) & Dec-Jan & $150-160$ & 46 & Present study \\
\hline
\end{tabular}


index based on eviscerated weight was around 22\% for both sexes, correlated with the phytoplankton increase (Chao et al., 1995). In PNG much variation was observed as some mature individuals were found nearly all the year round (Shelley, 1981). The unseasonal spawning behaviour may be caused by the close proximity to the equator, as suggested for other invertebrates (see Giese and Pearse, 1974). The presence of mature individuals all year round could be an argument for the aquaculture of this species, which presently gets a medium-good price on the trepang markets (Conand, 2008). However, a clear resting season appears from May to June and a major spawning season from November to March (Shelley 1981).

In New Caledonia, several populations of $A$. echinites have been studied for a number of years (1978 to 1982) showing a reproductive season from December to January (Conand, 1993). In La Réunion (see results and Fig. 6), the gonad-index based on eviscerated weight peaked around $21 \%$ in December. A second smaller peak of GI in April was certainly due to fewer mature specimens. Thus, this species is generally a summer spawner with possibly less distinct spawning peaks close to the equator. In general, most tropical aspidochirotide holothurians follow this trend, with one of the few exceptions being $H$. whitmaei which spawns in winter (Conand 1981; Shiell and Uthicke 2006).

Mean GI value calculated in December $(21 \%)$ in La Réunion was similar to that found by Chao et al. (1995) in Taiwan (22\%) during the spawning period.

Gonad-index variations help to understand the reproductive cycle such as spawning event but also some life history parameters such as fecundity. For example, the monthly maximum mean value of female gonad-index calculated using EW may give a first insight of the potential fecundity, taking the mean diameter of ripe oocytes into account. In Taiwan mean oocytes diameters is around 110 $\mu \mathrm{m}$ (Chao et al. 1995), a slighty smaller value than in PNG (Shelley, 1981), New Caledonia (Conand, 1993) and La Réunion (150-160 $\mu \mathrm{m}$ ), but preservation techniques may have differed between studies. Fecundity of A. echinites is rather high, as mentioned earlier and cited in the literature for New Caledonia (Conand, 1982, 1989, 1993) with values of absolute fecundity from $4.10^{6}$ to $25.10^{6}$ oocytes, compared to the weight of ripe ovaries from the different sites.

Concerning the influence of environmental factors on the reproductive cycle of A. echinites in La Réunion, as shown for H. leucospilota from La Réunion (Gaudron et al., 2008), the onset of gametogenesis seems to be triggered by the increase of solar illumination in July. However, for $A$. echinites both temperature and rainfall factors did not seem to control the reproduction.

Overall, the spawning season of A. echinites seems longer in lower latitudes, as found for other species where several study sites were compared (Conand, 1989; Gaudron et al., 2008). The size at first sexual maturity is difficult to compare between different studies because different parameters of weight were used and correlations between parameters were not available. In New Caledonia, sexual maturity is at $\mathrm{DW}_{50}$ equalled to $75 \mathrm{~g}$ corresponding to $\mathrm{EW}_{50}$ of $67 \mathrm{~g}$. In La Réunion (present study), the first maturity was at $\mathrm{EW}_{50}$ equalled to $46-55 \mathrm{~g}$. The presence of juveniles found in La Réunion on sea-grass beds nearby the studied site where mature specimen were sampled, as observed by Wiedemeyer (1994), supports the hypothesis of some migration during growth for this species (Conand, 1989).

\section{Reproductive parameters of holothurians from La Réunion}

Following the synthesis presented in Table 3 on H. atra, S. chloronotus, H. leucospilota and A. echinites, a few points need to be discussed. Population densities and biometrical parameters (TW and EW values) varied between both species and sites. This will need further analyses such as the effect of environmental and biotic factors (sediment, hydrodynamism, primary productivity and species interactions) to explain the patchy distributions of species and the carrying capacity of habitat.

The reproduction of the three species $H$. atra, S. chloronotus and H. leucospilota was characterised by the presence of both fission (asexual reproduction) and seasonal sexual reproduction (Conand 1996; Conand et al., 1997; Gaudron et al., 2008; Hoareau and Conand 2001, Conand et al., 2002, Uthicke and Conand 2005). These species displayed an unbalanced sex-ratio, 
which is rare in holothurian populations but already observed in fissioning species (Conand $e t$ al., 2002; Uthicke and Conand 2005). A. echinites reproduces only by sexual reproduction, but has an unbalanced sex-ratio. It would be useful to sample other populations of this species in la Réunion to prove if it is a local characteristic.

All the species studied have a main sexual reproductive season during the warm waters. However, some species present a minor spawning event a few months later, which could be only due to a few mature specimens, as the standard error of the mean (SEM) of the gonad-index was quite large at this time. Atresia was limited in spent gonads of $A$. echinites, compared to $S$. chloronotus (Conand et al., 2002) and H. leucospilota (Gaudron et al., 2008).

All these medium-sized species have a relatively small size (and weight) at their first maturity, as was found in New Caledonia (Conand 1989). It is possible to infer the potential fecundity from the gonad-index maximum monthly mean. It was much higher in $\mathrm{H}$. leucospilota (GI=42\%) (Gaudron et al., 2008), in agreement with the idea that larger species are more fecund (Conand 1993). GI of $S$. chloronotus was the lowest, in agreement with the results found in other species from the Stichopodidae family where gonad anatomy is different from the Holothuriidae (Conand, 1989, 1993). Therefore the medium-sized species studied in La Réunion present the same biological parameters in their reproductive strategy as those described in New Caledonia (Conand, 1989, 1993).

\section{Fishery management of holothurians in the WIO}

The management of sea cucumber fisheries to enhance sustainability is becoming an important issue in many regions (Lovatelli et al., 2004, Bruckner 2006, Conand 2006a, Conand 2008). It requires data on the population dynamics of the commercial species, which are generally still lacking. The sexual reproduction, if seasonal, is important to implement a harvest season and closure during the spawning (Table 5). The results obtained in La Réunion allow recommendations to be made for a seasonal closure during the warm waters season, from December to February. Asexual reproduction is important in some species, such as $H$. atra and S. chloronotus, during the cool season and thus this should also be taken into account. On the contrary, $H$. leucospilota and A. echinites display very little or no fission.

The size at first maturity is necessary to manage capture sizes (Conand, 2006a; Conand, 2008) which has a biological justification in maximizing the yield per recruit and allow individuals to spawn before harvest, and also an economic reason as larger individuals command a better price than smaller ones. The present results for A. echinites and the already published results for other species from $\mathrm{La}$ Réunion are presented as a synthesis for minimal weight value for capture (EW) (Table 5).

Recruitment is still poorly known for most species of sea cucumbers, particularly tropical ones (Conand, 1989; Shiell, 2004) although it is a vital parameter for fisheries management. The different reproductive strategies are likely to result in different patterns of recruitment. Species with a clear annual sexual reproduction may have a recruitment peak that should enable the discovery of small recruits in the field, though this has proven to be very rare throughout the Indo-Pacific (Conand 1989; Shiell 2004). Recruitment is probably occasional and may not happen in the same area as the parental population as migration may occur

Table 5: Management approach, based on sexual reproductive parameters of several species from La Réunion. (1) closure during the main reproductive season, at least; (2) minimum weight for capture EW (g)

\begin{tabular}{|c|c|c|c|c|c|}
\hline Species & $\begin{array}{l}\text { Main } \\
\text { reproduction } \\
\text { season }\end{array}$ & $\begin{array}{l}\text { Secondary } \\
\text { season }\end{array}$ & $\begin{array}{c}\text { Suggested } \\
\text { seasonal } \\
\text { closure }(1)\end{array}$ & $\begin{array}{c}\text { First } \\
\text { maturity } \\
(\text { EW g) }\end{array}$ & $\begin{array}{c}\text { Suggested } \\
\text { min weight } \\
(\mathrm{EW}) \text { limit }(2)\end{array}$ \\
\hline Holothuria atra & Warm Season & None & Dec.-Feb & - & - \\
\hline Stichopus chloronotus & Jan-Feb & Nov & Jan-Feb & 50 & $50 \mathrm{~g}-$ \\
\hline $\begin{array}{l}\text { Holothuria leucospilota } \\
\text { Actinopyga }\end{array}$ & Feb & May & Feb & 55 & $55 \mathrm{~g}-$ \\
\hline Echinites & Dec - Jan & April - May & Dec - Jan & 46 & $46 \mathrm{~g}-$ \\
\hline
\end{tabular}


during growth. In La Réunion, small recruits of both $S$. chloronotus and $H$. atra with high seasonal asexual fission rates were found, some originating from fission, but also some small normal individuals probably from sexual reproduction (Conand pers. obs.). For A.echinites, very small individuals were also found in a seagrass bed in Okinawa, Japan (Wiedemeyer 1994). In La Réunion, juveniles were also found in a sea-grass bed, near the back reef. These individuals are useful to follow the growth of the species, another parameter essential to understand the population dynamics and, for hatchery and mariculture experiments.

\section{CONCLUSION}

This study on A.echinites, the first for the WIO, with comments on other species (H.atra, S. chloronotus, H. leucospilota) from La Réunion, has provided a new set of data on the reproductive biology in the Indian Ocean which are useful for the fishery management. These results will also be useful for the regional WIO programme on sea cucumbers (Conand et al. 2006, Conand and Muthiga 2007) and approaches of integrated management.

Acknowledgments - The authors would like to thank Dr Rivière and the CHD of St Denis of La Réunion for the Histology sections. Project was funded by WIOMSA (Western Indian Ocean Marine Sciences Association) through a MASMA grant in 2006-2008.

\section{REFERENCES}

Bruckner, A.W. (ed). 2006. The Proceedings of the Technical workshop on the conservation of sea cucumbers in the families Holothuridae and Stichopodidae. NOAA Technical Memorandum 44,239 pp.

Clark, A.M. and Rowe F.W. (1971) Holothurioidea. In: Monograph of Shallow Water Indo-West Pacific Echinoderms. Trustees of the British Museum, London: 171-210.

Chao S.M., Chen C.P. and Alexander P.S. (1995) Reproductive cycles of tropical sea cucumbers (Echinodermata : Holothuroidea) in southern Taiwan. Mar. Biol., 122: 289-295.

Conand,C. (1981) Sexual cycle of three commercially important holothurian species (Echinodermata) from the lagoon of New Caledonia. Bull. Mar. Sci., 31(3): 523-544.

Conand, C. (1982) Reproductive cycle and biometric relations in a population of Actinopyga echinites (Echinodermata: Holothuroidea) from the lagoon of New Caledonia, Western Tropical Pacific. In: Echinoderms : Proceeding of the International Conference Tampa Bay. J.M. Lawrence (ed), Balkema, Rotterdam: 437-442.

Conand, C. (1989) Les Holothuries Aspidochirotes du lagon de Nouvelle-Calédonie: biologie, écologie et exploitation. Etudes et Thèses, O.R.S.T.O.M., Paris : $393 \mathrm{p}$.

Conand, C. (1993) Reproductive biology of the characteristic holothurians from the major communities of the New Caledonia lagoon. Mar. Biol., 116: 439-450.

Conand, C. (1996) Asexual reproduction by fission in Holothuria atra: Variability of some parameters in populations from the tropical Indo-Pacific. Oceanologica Acta 19, 3: 209-216.

Conand, C. (2001) Overview of sea cucumbers fisheries over the last decade - what possibilities for a durable management? Int. Echinoderms 2000, Barker (ed) Swets \& Zeitlinger: 339-344

Conand, C. (2004a) Present status of world sea cucumber resources and utilisation: An international overview: 13-23 In Lovatelli A., Conand C, Purcell S., Uthicke S., Hamel J.-F. \& Mercier A. eds. 2004 - Advances in sea cucumber aquaculture and management. FAO Fisheries Technical Paper No. 463, 425 pp.

Conand, C. (2004b) Monitoring a fissiparous population of Holothuria atra on a fringing reef on Reunion Island (Indian Ocean). S.P. C. Bêchede-mer Information Bull 20: 22-25.

Conand, C. (2006a) Sea cucumber biology: taxonomy; distribution; biology; conservation status: 30-46 In Bruckner, A.W. (ed). 2006. The Proceedings of the Technical workshop on the conservation of sea cucumbers in the families Holothuridae and Stichopodidae. NOAA Technical Memorandum 44, 239 pp.

Conand, C. (2006b) Harvest and trade: utilization of sea cucumbers; sea cucumber fisheries; current international trade; illegal, unreported and unregulated trade; bycatch; socio-economic characteristics of the trade in sea cucumbers: 47-69 In Bruckner, A.W. (ed). 2006. The Proceedings of the Technical workshop on the conservation of sea cucumbers in the families Holothuridae and Stichopodidae. NOAA Technical Memorandum 44, 239 pp.

Conand C. 2008. Population status, fisheries and trade of sea cucumbers in Africa and Indian ocean. In: 
Toral-Granda, V.; Lovatelli, A.; Vasconcellos, M. (eds) Sea cucumbers. A global review on fishery and trade. FAO Fisheries Technical Paper. No. 516. Rome, FAO. 2008.319 p.

Conand, C. \& Mangion, P. (2002) Holothurians from La Réunion fringing reefs: diversity, distribution, abundance and population structure. S.P.C. Bêchede-mer Information Bull., 17: 27-33.

Conand, C. and Muthiga, N. (Eds) (2007) Commercial Sea Cucumbers: A Review for the Western Indian Ocean. WIOMSA Book Series No. 5, 66 pp.

Conand, C., Morel C., and Mussard R. (1997) A new case of asexual reproduction in holothurians: Fission in Holothuria leucospilota populations on Reunion island in the indian ocean. S.P.C. Bêchede-mer Information Bull., 9: 6p.

Conand, C., Jerome, A., Dijoux, C. and Garryer, J. (1998) Fission in a population of Stichopus chloronotus, on Reunion island, Indian Ocean. Bêche-de-mer Information Bull., 10: 15-23

Conand, C., Muthiga, N., Aumeeruddy, R., De La Torre Castro, M, Frouin, P, Mgaya, Y, Mirault, E, Ochiewo , J. and Rasolofonirina, R. (2006) A three years regional project on sea cucumbers in the south-western indian ocean : national and regional analyses to improve management S.P.C. Bêche-de-mer Inf. Bull., 23: 11-15.

Conand, C., Uthicke, S. and Hoareau, T. (2002) Sexual and asexual reproduction of the holothurian Stichopus chloronotus (Echinodermata) : a comparison between La Réunion (Indian Ocean) and east Australia (Pacific Ocean). Invert. Reprod. Develop. 41 (1-3): 235-242.

Conand, F., Marsac, F., Tessier, E. and Conand C. (2007) A Ten-year Period of Daily Sea Surface Temperature at a Coastal Station in Reunion Island, Indian Ocean (July 1993-April 2004): Patterns of Variability and Biological Responses Western Indian Ocean Journal of Marine Science, Volume 6(1): 1-16.

Gaudron, S.M., Kohler, S.A. and Conand, C. (2008). Reproduction of the sea cucumber Holothuria leucospilota in the Western Indian Ocean: biological and ecological aspects. Invert. Reprod. Develop. 51: 19-31

Giese, A.C. and Pearse, J. S. (1974). General principles. In: Reproduction marine invertebrates. A.C. Giese and J.S. Pearse (eds). Academic press, New York, pp. 1-49.
Hoareau, T. and Conand, C. (2001) Sexual reproduction of Stichopus chloronotus, a fissiparous sea cucumber, on Reunion Island, Indian Ocean.S.P.C. Bêche-de-mer Information Bull., 15: 4-12.

Lovatelli, A., Conand, C., Purcell, S., Uthicke, S., Hamel, J.-F. and Mercier,A. eds. (2004) Advances in sea cucumber aquaculture and management. FAO Fisheries Technical Paper No. 463, 425 pp.

Muthiga, N. A., Kawaka, J. A. \& Ndirangu, S. (2007) The Reproductive Biology of the Commercial Sea Cucumbers Holothuria fuscogilva and $\mathrm{H}$. scabra along the Kenyan coast. $5^{\text {th }}$ Wiomsa scientific Symposium. Durban 2007 (abstract).

Rasolofonirina, R., Vaïtilingon, D., Eeckhaut, I. and Jangoux, M. (2005) Reproductive Cycle of Edible Echinoderms from the South-Western Indian Ocean. II: The sandfish Holothuria scabra (Jaëger, 1833). Western Indian Ocean Journal of Marine Science 4: 61-75.

Shelley, C.C. (1981) Aspect of reproduction, distribution, growth and fishery potential of holothurians (beche-de-mer) in the Papuan coastal lagon. Ms thesis, University of Papua New Guinea.

Shiell, G. (2004). Field observations of juvenile sea cucumbers. S.P.C. Bêche-de-mer Information Bull., 20: 6-11

Shiell, G. and Uthicke, S. (2006) Reproduction of the commercial sea cucumber Holothuria whitmaei (Holothuroidea: Aspirochirotida) in the Indian and Pacific Ocean regions of Australia. Mar. Biol. 148: $973-986$.

Uthicke S., Conand, C. and Benzie, J. A. H. (2001) Population genetics of the fissiparous holothurians Stichopus chloronotus and Holothuria atra (Aspidochirotida): a comparison between Torres Strait and La Réunion. Mar. Biol. 139: 257-265

Uthicke, S. and Conand, C. (2005) Amplified fragment length polymorphism (AFLP) analysis indicates importance of both asexual and sexual reproduction in the fissiparous holothurian Stichopus chloronotus (Aspidochirotida) in the Indian and Pacific Ocean. Coral reefs, 24(1): 103-111.

Wiedemeyer W.L. 1994 Biology of small juveniles of the holothurian Actinopyga echinites: growth, mortality, and habitat preferences. Mar. Biol. 120: 81-93. 
